УДК: 7.03

ББК: 85.149

A43

DOI: $10.18688 / \mathrm{aa} 177-10-72$

Ekaterina Staniukovich-Denisova, Elizaveta Baryshnikova

\title{
The Aegina of Gleb Bogomolov: Painting as an Artifact
}

\begin{abstract}
And, may be, we already live in the state of Apocalypse today, but it is not for several days. Is it for many years, is it even longer? All those revolutions, wars and catastrophes: it's it; but is it a Small Apocalypse so far? But, sometime, it will be over, and the Morning will come: The Morning of the first day immediately after... What will it be? And what is your first Step?
\end{abstract}

Gleb Bogomolov [4]

In 2016 the International Conference "Actual Problems of Theory and History of Art VII" with the discussion focusing on "Artifact, Art-object, Argument. An object in Visual Arts: Tasks, Methods, Results" chose the "Aegina. 1063" by Gleb Bogomolov as its emblem. Painted in 2004, this large-scale canvas $(195 \times 145 \mathrm{~cm})$ represents the last, perhaps the most brilliant period of the master. The Organizing Committee approved the emblem in just a couple of weeks before Bogomolov's death in March 2016.

"Artifact" was a favorite word, with the help of which Bogomolov determined the quality of his complex, filigree paintings organically including text, fragments of cloth, and gold leaf on textured gesso. From the end of the 1960s, in fact being the first in the country, the artist begins to work programmatically with an open gold in contemporary painting [5].

The painting of 2004 is a part of the "Aegina" cycle, which was bethought after the artist's visit to the Greek island in 1998 and was being embodied in over a decade. The composition of the bigger part of the pictures of the cycle is centered on the lone monolith of the Doric column, giving a wide field for interpretation of the Pillar image, tectonic support or anthropomorphic associations. At first sight, the chosen picture is maximally close to the plot specifics - flooded with light Athena Aphaea temple (Ill.43) column is represented on the background of shrill blue of the sky. Thanks to the multilayerity and luminosity of the coloring dough, the picture's color and composition vary greatly depending on the light. In the oblique light with different intensity and at different angles unseen and over-painted elements start to appear: the glow of fust changes from golden to silver. Separately highlighted, either the blood drips from the invisible crown of thorns on the capital (the head), or large chopped letters GLEB BOGOMOLOV running at the edge of the column, or the pictographs at its basement acquire a dominant role. 
Multichannelity of Bogomolov's creativity allowed choosing his work as an emblem, in which, as in cultural code, one can read many meanings, associated with the problems of contemporary art history and museology considered at the conference.

During a press conference in the Petrovsky Hall of Saint Petersburg State University on the conference opening day (October 11, 2016), a presentation-performance of G. Bogomolov's painting, as the conference emblem, was held. The author of the performance concept Anna Bystrova (M. A., Institute of History of Saint Petersburg State University) sought to reflect Gleb Bogomolov's thoughts on the purpose of creativity, his desire to pay tribute to the rejected artists, not recognized in time. So, according to her, the revealing temporal context column represents the surviving part of the acropolis, which served as a refuge for the Aegina citizens. During the press conference, the picture placed on a working easel was covered with a stained curtain, which symbolized the presence of the artist in his studio at the artifact's birth. A short performance was to reveal the life of the artifact in the museum space. Performers (Anna Bystrova and Vasilisa Zhinkina) removed the veil and projected the flashlight onto a solitary column to fill it with energy, light, life itself, just as the Aegina acropolis once had been. While the action goes on the viewers try to catch the gleam of the golden column, and the performers continue the process of examining and attributing the art piece. They perform studying the painting in X-, ultraviolet, and infrared rays, oblique light (Ill.163). After the 'expertise', the picture is placed 'on display' in the luxurious baroque space of the Petrovsky Hall, once the seat of the Senate of the Russian Empire in the building of the Twelve Colleges.

* * *

Gleb S. Bogomolov (1933-2016) belonged to the generation of Russians born before the Second World War and survived the horrors of the most lethal Siege of Leningrad [9]. The war echoed in brutal coloring of his early works and frightening imagery of monstrous humans [6, p. 24], shot stuff or handicapped statues.

His active work in the 1960s - early 2000s coincided with the Soviet, post-Soviet and contemporary periods of Russian art. Gleb Bogomolov was born and worked all his life in Leningrad (historically and currently (since September 1991) known as St. Petersburg) and thus, inheriting the traditions of the St. Petersburg artistic culture and going the way of non-conformism and "respectable modernism" [15] in art, was considered to be an artist who deeply felt and faithfully conveyed the genius loci.

What actually gives the right to consider G. Bogomolov a respectable modernist, although he worked at a time when post-modernism was already dominating in the West?

Respectable? Oh, sure. Especially in his later works, refined and luxurious, really precious (with insertion of gold sheets in the paints dough) since the 1990s. Absolutely recognizable manner. An esthetic approach to color and texture. Extremely serious attitude to art. The model biography for the contemporary artist - from a rebel to a master - featured an adventurous character, the change of various professions in his youth, the refusal to study in official art institutions, the first exhibition in 1974 at the DK Gaza [10, pp. 171, 277, 367, 377, 389, 393]. Strip, active participation in the non-conformist movement, and finally, a success with professionals, respectable galleries (Alla Bulyanskaya, Marina Gisich), and art lovers. 
Let's try to figure out what the obvious complication of Bogomolov's creativity in the modernism of the $20^{\text {th }}$ century is.

Thus, his art can be divided into two major periods: a nonconformist (in the Soviet period) and respectable (as already said, about 15-20 years of the final period, until the artist's prolonged illness).

His early works are spread in different collections all over world, some in the private collections of the city (only a few, at the exhibition in the Museum of Non-Conformist Art). Therefore, the most integral impression can be given by a retrospective album (the series "Avant-garde on the Neva"), including more than 100 paintings from the 1970s-1980s [2; 7]. Most were figurative, painted under the perceptible influence of symbolism and expressionism, which is very indicative of the corresponding domestic nonconformism. Gloomy coloring, pasty brushwork, translucent texture of a rough canvas as if put without a primer. It

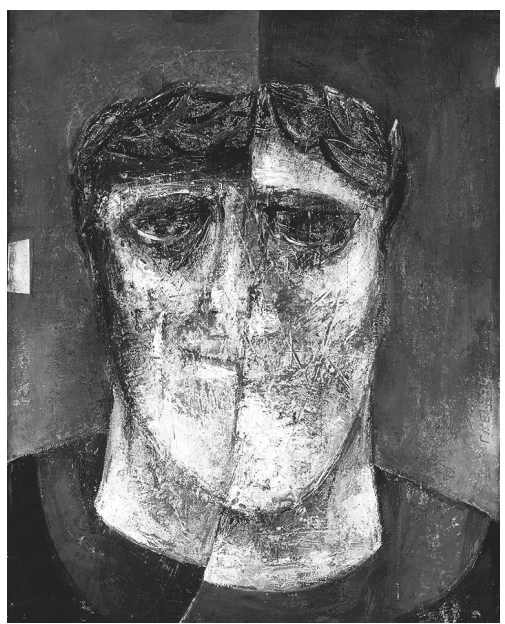

Fig. 1. Gleb Bogomolov. Fragmental Portrait of Antique Hero. $1984.100 \times 80 \mathrm{~cm}$, mixed media on canvas. Private collection. Photo by T. Bogomolova was obviously the phase of search, experiment, and all sorts of allusions to European and Russian art of the first half of the $20^{\text {th }}$ century: F. Bacon, A. Marquet (At the German Cemetery, 1960, Urban Landscape, 1959, 1977), P. Gauguin (By the Sea, 1965), D. de Chirico, in Bogomolov's desert landscapes the naked figures replaced de Chirico's mannequins (Antique Landscape, 1976; Conversation, 1978). One could feel Bogomolov's aspiration to generalize the images, to avoid extra detailing. The faces of his characters turned into some coarse masks, either with a Bruegel-like wry smile, or of a thoughtlessly criminal in apartness (Fig. 1). Bogomolov called them the 'archetypes', and went back to this motif throughout his life. Bald toothless heads without a nape, with coarse facial features: a forward jaw, a straight nose spilled over the forehead, with gaping eye sockets, they point out the image of a fighter (a gladiator and a criminal) with reference to the Late Roman bronzes and mosaics. The artist was looking for an adequate reflection of the contemporary problems that worried him in the images of antiquity. There the motif of fate, destiny and an ominous game is intertwined, outlined by depicting (or collaged) playing cards, surrounding characters or even nailed to their forehead (The Crusade Ace, 1978). Often these are severed heads, "anonymous portraits", "targets", filling almost the entire space of huge (appr. $120 \times 100 \mathrm{~cm}$ ) paintings. Contemporaries read them as portraits of members of the Politburo (Political bureau is the executive committee for Communist Parties), as iconostasis of monsters. At the same time, the artist claims the incredible dignity of his characters, torturers, unrepentant sinners in pride, heroes in laurel wreaths, crowns or thorns (Fragmentary Portrait of an Ancient Hero, 1984; the series Mythical heroes etc.) (Ill. 157). As if the artist avoids showing the human nature, not able to transfer divine image and that's why focuses on display of the demonic one. Ideas that were common in the Russian pre-revolutionary culture, for example, Mikhail Vrubel's art and Aleksandr Blok's poetry [16]. According to his wife Tatiana Bogomolo- 


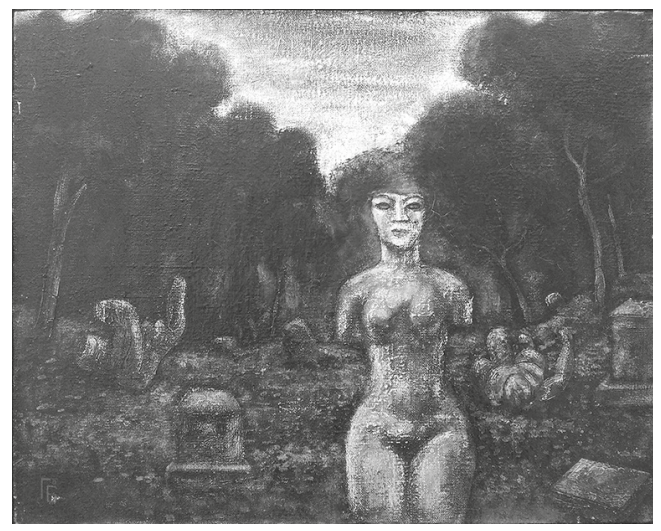

Fig. 2. Gleb Bogomolov. Phantom IX. 1975, oil on canvas. The Museum of Nonconformist Art, St. Petersburg va, Gleb always noticed "vice sealed faces" in the crowd and studied them ${ }^{1}$.

One can notice some similarity of his almost peer Oleg Tselkov (his friend since 1958), who consistently developed images of a deformed human face and figures in which it is customary to see the opposition of the individual and the social system. The difference is that Bogomolov's imagery, artistic devices were exaggerated through expressionism, directly based on the classical tradition, so he becomes its interpreter, affirming "eternal", intuitively often pre-Christian, values. Another series inspirited by antiquity theme belongs to the 1970s. If in the powerful male images the focus was on the face-mask, in the "Parks" one sees female mask-bodies, naked armless torsos with masked heads and smiles of archaic cores, contrasted to the "alive" marble statues that preserve the integrity and plasticity of poses on the dense background of the garden greenery (Fig. 2).

Another motif Bogomolov worked out throughout his life was the "Target". The artist said that the impetus came from his childhood impression, when he saw a bloodstained and hollow-looking vest in ruined St. Theodore's Cathedral of Tsarskoe Selo. There are a number of works in which Bogomolov's "archetypes" found themselves in the red scope of the sight. They are increasingly losing their individual features, becoming flat plywood targets - bodies with head deprived of face and hands. This silhouette generalization gradually takes away from narrativity and allows us to concentrate on the texture and color.

G. Bogomolov's painting of this time is filled with various mythologems, generally indicative of a non-conformist culture, which was one of the ways to escape from Soviet reality in the imaginary world, studying the "psychological space of previous times and civilizations Byzantium, Jerusalem, Babylon" (G. Bogomolov). Tatiana Shekhter, who studied Bogomolov's art a lot, was convinced that time in his paintings, as in the works of postmodernism, loses its chronological order and the whole history turns into a single event in which all the temporal structures are similar to each other [13, p. 15].

There is a feeling that most of the works of this long period combined the theme of the 'game', the 'substitution' of Life, namely the mimesis in its primitive power, corrected for the Nietzschean "eternal return".

The gradual transition from mythological to religious consciousness is traced in his art since the mid-1980s marked by emerging of some Christian images [7;8], for example, bowls (chalices) (Fig.3), of clearly visible Byzantine impact or using some composition schemes of icons with stamps (Transit-1, 1991). New, originally nameless, series of "Byzantium" (Ill. 158), "Crosses", "Mandorla", "Maphoria" (Ill. 159) [14; 11; 12, p.351-352] ... The study of icon paint-

$1 \quad$ Interview with Tatiana Bogomolova 14.11.2017. 
ing leads to enlightenment and conscious harmonization of a complexly elaborated color scheme. Some changes occured not only at the level of plot, the degree of generalization also increased, which led to what is commonly called "abstract art". The endto-end numbering of the chronology of the paintings, marked in the diary replaced the titles.

Some techniques used before were fused into a single system of means of expression, which allowed the artist to solve new problems. Work experience in the theater, as well as in jewelry art, determined Bogomolov's special attention to the texture. It is no coincidence that he used to call his works "artifacts", asserting their aesthetic value and also "reanimation objects" [4]. As a basis for painting, he could take old boards, countertops, other pieces of furniture. When working in mixed technique, he introduced the elements of the collage: foil, paper stickers

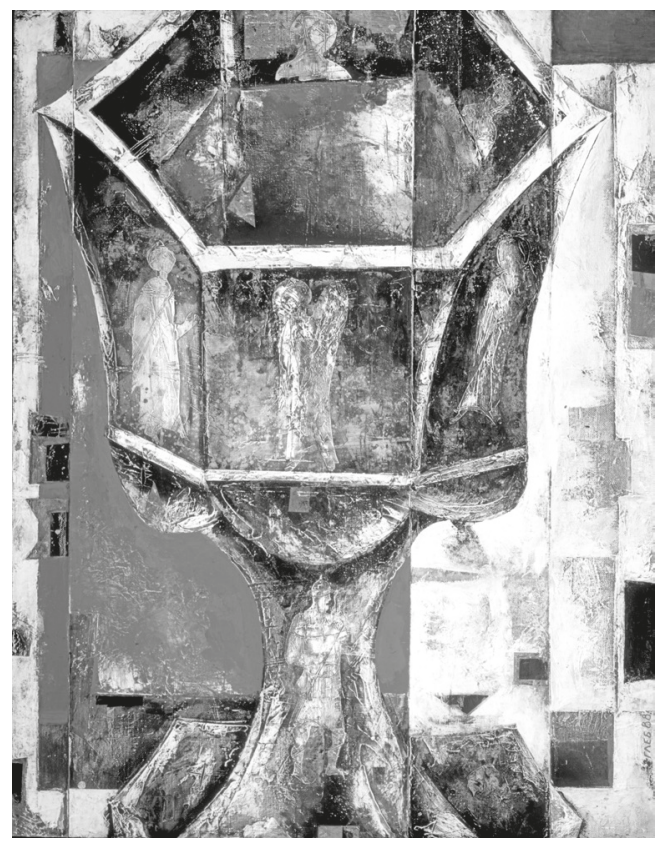

Fig. 3. Gleb Bogomolov. Bowl 45. 1988. $120 \times 95 \mathrm{~cm}$, mixed media on canvas. Private collection. Photo by T. Bogomolova and scraps in the dough [1, p.67]. The emergence of the "Texts" series at the turn of the 1980s and 1990s reflects his interest in semiotic systems, which will be organically and delicately included in his art in the form of scratched badges or short inscriptions that shine through the top layer of painting.

Until the mid-1990s despite the talent and the unique creativity, Gled Bogomolov was engaged "in sorting out" the tools, mastering the techniques of world art, which objectively remained unknown because of the "iron curtain" in the 1950s and 1960s. First were primarily the post-impressionists, the Quattrocento romance of youth, then the early Surrealists and Expressionists, the Tashists, the storerooms of the Russian Museum, in which, as Bogomolov recalled, "Erzia was fascinated, and Larionov with his Venus just turned everything in me. Chagall... Kandinsky on the glass... Everything that wandered in me indistinctly made sense and fell into place. It was almost like a baptism..." [2, p. 13]. Then followed close communication with Valentin Gromov, Aleksandr Arefiev, Evgeny Rukhin (whose work with the texture, the linings of the canvas on the ground, undoubtedly exerted its influence). And since the late 1980s all the opportunities to see the world and the world art from antiquity to the last decades - medieval miniatures, Byzantine mosaics, Miró, Pollock, Kiefer... were open. The spirit of contradiction was pacified, and a holistic, productive period of monologic utterances of the artist and person began.

The first period is well decomposed and analyzed in the context of the development of the Leningrad non-conformism, which has been the subject of many recent studies. In our opinion, Bogomolov's more significant contribution to art is represented by the works of the late $20^{\text {th }}$ and 
early $21^{\text {st }}$ century, by which he sums up his work. These are confident works of the master, finally having found his way of expression and absorbed in the consistent and detailed development of the knowingly unknowable.

These are the conditionally 'abstract' works that deepen and unite previously voiced topics in close touch with Christian art: archetypes, maphoria, shrouds (Ill. 160), arks, pillars (Ill. 162). It is interesting to trace the transformation of images preserving a formal composition: from a desperate bloody (Ill. 161), thoughtless and soulless victim (shot through a "target", an impersonal man opposing the system) to a bodily/disembodied being standing on the border of two realities ("maphoria").

In his interviews $[2 ; 3 ; 10]$, the artist constantly spoke of the unity of time and space, which he tries to experience and convey through the display of an intangible transition from real space into picture. He called this space post-apocalyptic. The scale of the task corresponded to the scale and monumentality of the work. At the same time, these paintings almost lack the pride of self-expression, but rather represent a way of mastering a multilayer incomprehensible world through its fragment.

The latent presence of the search for the ideal, the religious consciousness generally inherent in Russian culture, the desire to overcome deformation, to the integrity of perception and aesthetic harmony, allow us to confirm the strong and substantive connection of Bogomolov's artifacts to the art of pre-post-modernist ideology.

Bogomolov's pictures basis were often the boards that were once the elements of the furniture (countertops, cabinet doors and shelves). This early-formed - in the era of non-conformity - technique subsequently acquired a power of deep symbolic conceiving and substantiating. Poetry, theatre, jewelry experience together with passion for expressionist rebelliousness of the 1970s melted together by the end of the artist's life into the flow of large abstract paintings-statements. Gleb Bogomolov regarded them as a distinct post-apocalyptic vision of reality that exists beyond time and space, here and now. "The historically established vast area of aesthetic sojourn... I am trying to escape therefrom into a something which is not yet an area but could conceivably become one" (G. Bogomolov, 1995) [15]. In fact, the attempt of viewing by spiritual sight, to transmit the presence of the other world and the divine light in the perceived reality leads the artist to the pictorial interpretation, drawing the system of artistic methods from Byzantine art. The clear allusions are expressed by colour, golden backgrounds, not infrequent pavolokas, koloks and kovtchegs. The artifact surface is a fabric woven from aged in some places, fragmentarily ruined or restored regenerating material.

Bogomolov's multi-channeled art allowed choosing Aegina as an emblem, in which, as in cultural code, one can read many meanings, associated with the problems of contemporary art history and museology, traditions and innovations, reservation and restoration, discussed at the 2016 conference and the perspectives and horizons to be discussed at the 2018 conference in Moscow. 


\section{References}

1. Bernstein D. et al. The Russian Museum Presents: Collage in Russia $20^{\text {th }}$ Century, almanac, no. 126. Saint Petersburg, Palace editions Publ., 2005 (in Russian).

2. Bogomolov G. Artist's Monologue. Gleb Bogomolov: (Series: Avangard na Neve). Saint Petersburg, P.R.P.Publ., 2007, pp. 9-17 (in Russian).

3. Bogomolov G. Gleb Bogomolov: Position of the Artist in the Modern World. Transcript of the Meeting. Metafizicheskie issledovaniia (Metaphysical Research), vol. 7. Saint Petersburg, 1998, pp. 318-324 (in Russian).

4. Bulyanskaya A. (ed.). Gleb Bogomolov. Painting. Grafics. Objects. Catalogue of the Exhibition. Moscow, Alla Bulyanskaya Gallery Publ., 2001. (in Russian).

5. Corazzola P. (ed.). Farbe Gold, Dekor, Metapher, Symbol, Beweggründe für die Malerei heute. Berlin, Ars Nicolai Publ., 1992. 128 p. (in German).

6. Finckh G.; Nannen H. Glastnost. Die Neue freiheit der Sowietischen Maler. Emden, Kunsthalle in Emden Publ., 1988. 116 p. (in German).

7. German M. To the Happy Few. Gleb Bogomolov: (Series: Avangard na Neve). Saint Petersburg, P. R. P. Publ., 2007, pp. 4-8.

8. German M. Visual Universals of Gleb Bogomolov. The Russian Museum Presents: Gleb Bogomolov, almanac, no. 76. Saint Petersburg, Marina Gisich Gallery, Palace editions Publ., 2004, pp. 10-13 (in Russian).

9. Gurevich L. Khudozhniki leningradskogo andegraunda: Biograficheskii slovar' (Artists of the Leningrad Underground: Biographical Dictionary). Saint Petersburg, Iskusstvo-SPB Publ., 2007. 320 p. (in Russian).

10. Kovalsky S. (ed.). Iz padeniia v polet. Nezavisimoe iskusstvo Sankt-Peterburga. Vtoraia polovina XX veka (From Falling into Flight. Independent Art of St. Petersburg. Second Half of the $20^{\text {th }}$ Century). Saint Petersburg, P. R. P. Publ., 576 p. (in Russian).

11. Kuznetsov E. D. Further Is Silence: Gleb Bogomolov and His Maphoria. Grafinia pokidaet bal (The Countess Leaves the Ball: Articles and Memoirs). Moscow, Artist - Rezhisser - Teatr Publ., 2010, pp.276-290 (in Russian).

12. Shekhter T. E. Art as an Image of the World: Selected Works on the Theory and History of Art. Saint Petersburg, St. Petersburg State University of Humanities Publ., 2012. 390 p. (in Russian).

13. Shekhter T.E. Gleb Bogomolov, Or Equilibrium of Nonequilibrium. The Russian Museum Presents: Gleb Bogomolov, almanac, no.76. Saint Petersburg, Marina Gisich Gallery, Palace editions Publ., 2004, pp. 14-17 (in Russian).

14. Shikhireva O. Flight to Byzantium. The Russian Museum Presents: Gleb Bogomolov, almanac, no. 76. Saint Petersburg, Marina Gisich Gallery, Palace editions Publ., 2004, pp. 18-19 (in Russian).

15. Tcherniavski T.; Sherkunov A. (eds.). Respectable Modernism. Modern Art of St. Petersburg: Artists about Art and Themselves. Saint Petersburg, Palitra Gallery \& Savva Trade House Publ., 1996. 66 p. (in Russian).

16. Tsvetaeva M.N.; Sokurova O.A. Some Aspects of Spiritual and Aesthetic Problematics of the Silver Age in the Works of M. Vrubel and A. Blok. Actual Problems of Theory and History of Art: Collection of articles, vol. 7. S. V. Mal'tseva; E. Yu. Stanyukovich-Denisova; A. V.Zakharova (eds.). Saint Petersburg, St. Petersburg University Publ., 2017, pp.636-645. Available at: http://dx.doi.org/10.18688/aa177-8-65 (accessed 20 December 2017) (in Russian).

Title. The Aegina of Gleb Bogomolov: Painting as an Artifact.

Authors. Staniukovich-Denisova, Ekaterina Iur'evna - head lecturer. Saint Petersburg State University. Universitetskaia nab., 7/9, 199034 St. Petersburg, Russian Federation. e.stanyukovich-denisova@spbu.ru

Baryshnikova, Elizaveta Vladimirovna - B. A., post-graduate student. Saint Petersburg State University. Universitetskaia nab., 7/9, 199034 St. Petersburg, Russian Federation. e.baryshnikova@spbu.ru

Abstract. In 2016 the International Conference "Actual Problems of Theory and History of Art VII" with the discussion focusing on "Artifact, Art-object, Argument. An object in Visual Arts: Tasks, Methods, Results" chose as its emblem the painting "Aegina" by the St. Petersburg artist Gleb Bogomolov. This large-scale painting becomes the starting point for analyzing the final period of the master's work in the context of the classical tradition in contemporary art interpretation.

Bogomolov's multi-channeled creativity allowed choosing his work as an emblem, in which, as in cultural code, one can read many meanings, associated with the problems of contemporary art history and museology discussed at the conference. 
Keywords: Gleb Bogomolov; Russian painting; artifact; Aegina; emblem; actual problems of theory and history of art.

Название статьи. Эгина Глеба Богомолова: живопись как артефакт.

Сведения об авторах. Станюкович-Денисова Екатерина Юрьевна - старший преподаватель. Санкт-Петербургский государственный университет. Университетская наб., д. 7/9, Санкт-Петербург, Российская Федерация, 199034. e.stanyukovich-denisova@spbu.ru

Барышникова Елизавета Владимировна - студент магистратуры. Санкт-Петербургский государственный университет. Университетская наб., д.7/9, Санкт-Петербург, Российская Федерация, 199034. liz4photo@ya.ru

Аннотация. В 2016 г. картина петербургского художника Глеба Богомолова из серии «Эгина» была выбрана эмблемой VII международной конференции «Актуальные проблемы теории и истории искусства» с дискуссионным акцентом «Артефакт. Арт-объект. Аргумент. Объект в изобразительном искусстве: задача, метод, результат». Это масштабное полотно становится отправной точкой для анализа интерпретации классической традиции в искусстве Богомолова.

Многоканальность творчества художника позволяет рассматривать его работу как своеобразный культурный код, в котором можно прочитать смыслы, сопряженные с проблематикой современного искусствознания и музейного дела, рассматриваемой на конференции.

Ключевые слова: Глеб Богомолов; русская живопись; артефакт; Эгина; эмблема; актуальные проблемы теории и истории искусства. 


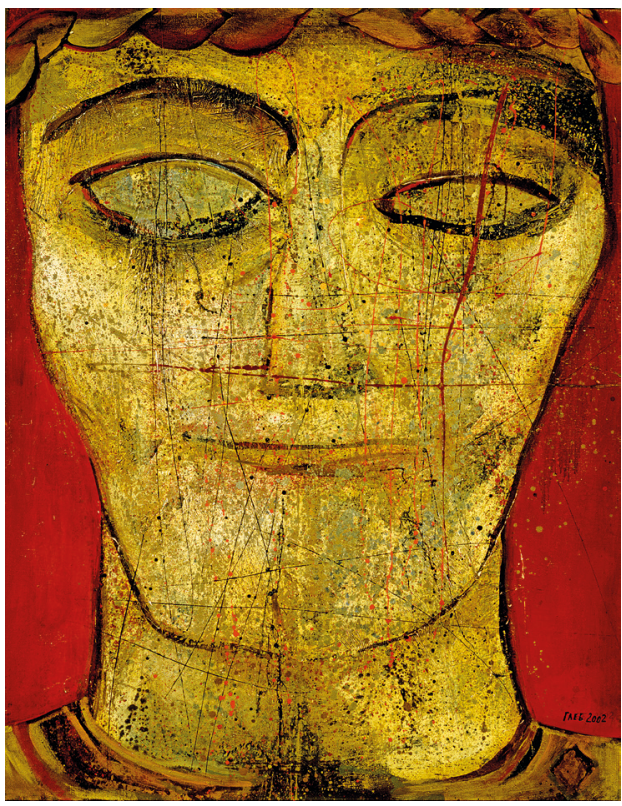

Ill. 157. Gleb Bogomolov. From the series 'Mythical heroes'. 2002. $130 \times 100 \mathrm{~cm}$, mixed media on canvas. Private collection. Photo by T. Bogomolova

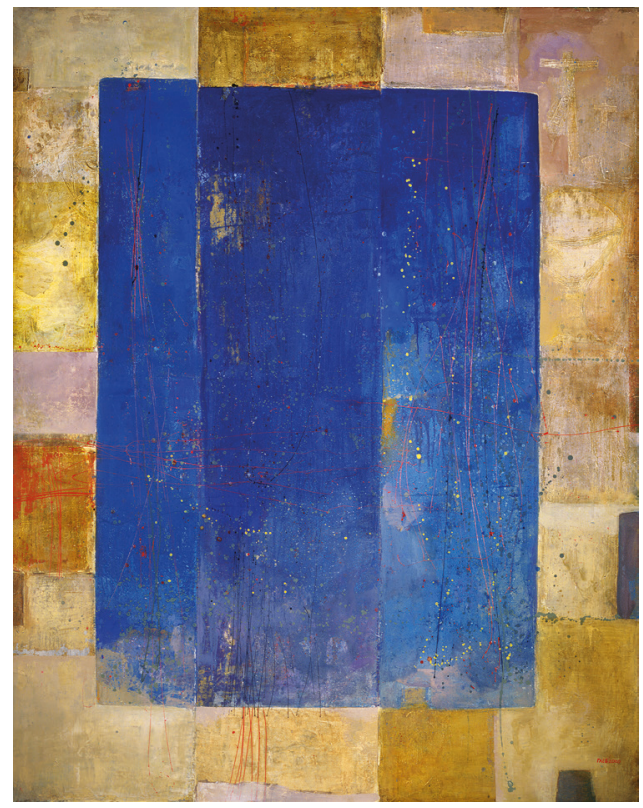

Ill. 158. Gleb Bogomolov. Byzantium 883-15. 2000. $215 \times 167 \mathrm{~cm}$, mixed media on canvas. Private collection. Photo by T. Bogomolova

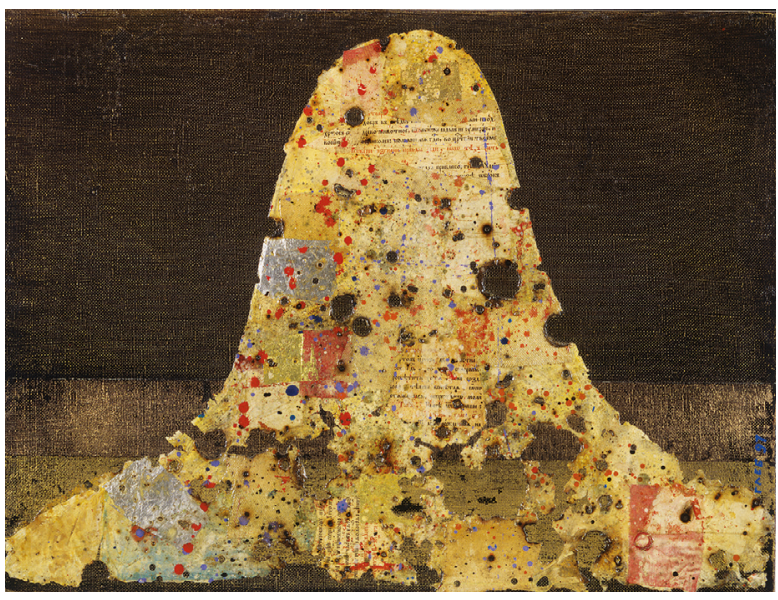

Ill. 159. Gleb Bogomolov. Maphorion. $1997.80 \times 100 \mathrm{~cm}$, mixed media on canvas. Private collection. Photo by T. Bogomolova

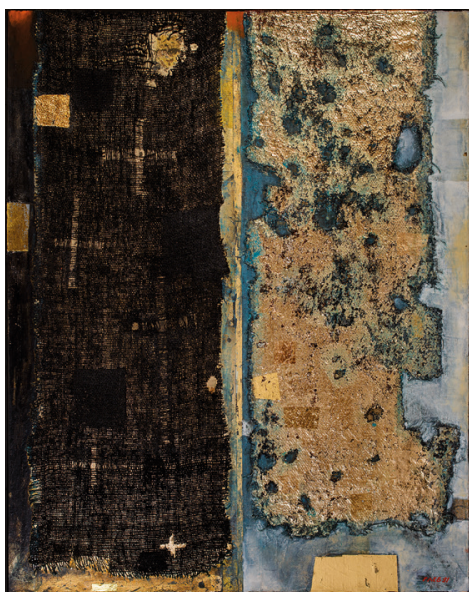

Ill. 160. Gleb Bogomolov. The Shroud 256. 1991. $150 \times 120 \mathrm{~cm}$, mixed media on canvas. Private collection. Photo by T. Bogomolova 


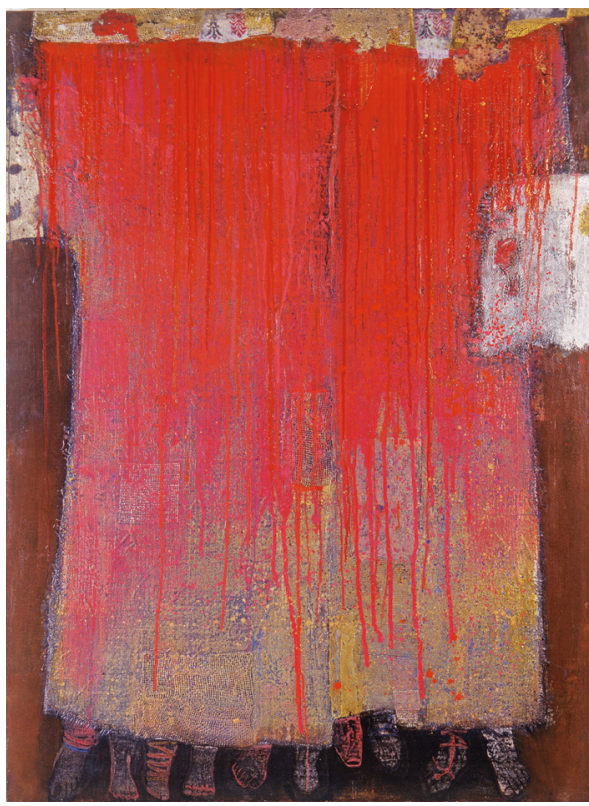

Ill. 161. Gleb Bogomolov. Death of Nero. 1999. $195 \times 146$ $\mathrm{cm}$, mixed media on canvas. Private collection. Photo by T. Bogomolova

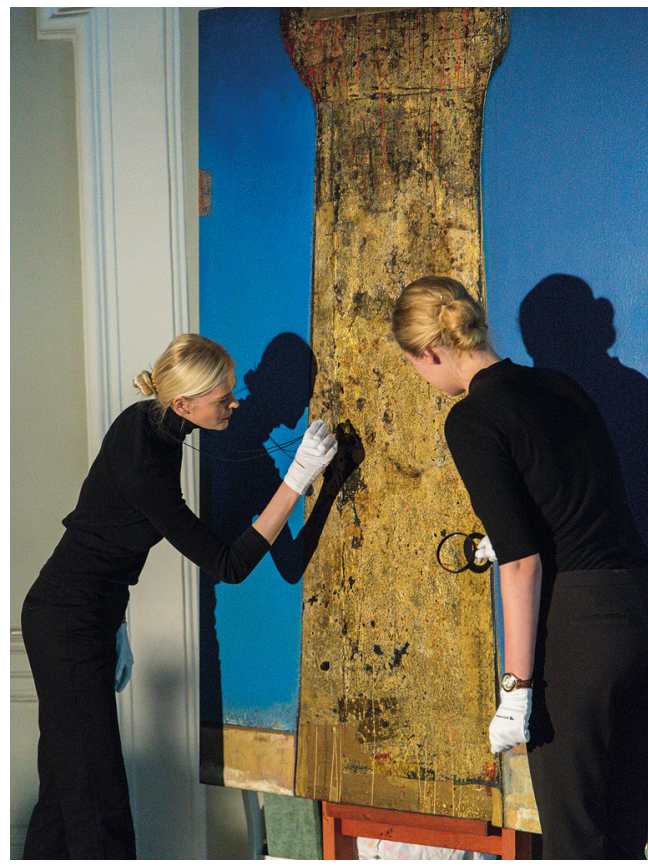

Ill. 163. Presentation of 'Aegina' by G. Bogomolov as the emblem of VII Actual Problems of Theory and History of Art International Conference, 11 October 2016, St. Petersburg. Photo by E. Baryshnikova 